\title{
Cookies made from mangrove (Bruquiera gymnorrhiza) fruit and soybean (Glycine max) flour
}

\author{
1,2, ${ }^{*}$ Afifah, D.N., ${ }^{1}$ Alamsyah, A.A.M., ${ }^{1}$ Huwaida, A., ${ }^{1,2}$ Nissa, C., ${ }^{1,2}$ Wijayanti, H.S., \\ ${ }^{1,2}$ Purwanti, R., ${ }^{1}$ Hastuti, V.N. and ${ }^{3}$ Sugianto, D.N. \\ ${ }^{1}$ Department of Nutrition Science, Faculty of Medicine, Universitas Diponegoro, Semarang, 50275, \\ Indonesia \\ ${ }^{2}$ Center of Nutrition Research (CENURE), Universitas Diponegoro, Semarang, 50275, Indonesia \\ ${ }^{3}$ Department of Oceanography, Faculty of Fishing and Marine Science, Universitas Diponegoro, Semarang, \\ 50275, Indonesia
}

\begin{abstract}
Article history:
Received: 1 March 2021

Received in revised form: 30

April 2021

Accepted: 2 May 2021

Available Online: 28 July

2021

Keywords:

Cookies,

Hydrogen cyanide,

Mangrove fruit,

Nutrient content,

Tannin

\section{DOI:}

https://doi.org/10.26656/fr.2017.5(S3).001
\end{abstract}

\begin{abstract}
Demak is an area in Indonesia with a high stunting rate of $50.28 \%$. Mangrove fruit, a major regional commodity, should be used as a basis for Supplementary Feeding Program (SFP) cookies to overcome stunting in Demak. This study was aimed to analyse the nutritional content, nutrition absorption inhibiting agents, and acceptance of mangrove fruit cookies. This research used a completely randomized sample with a one-factor design to formulate mangrove and soybean flour. The formulations used were F1 $(60 \%$ : 40\%), F2 (70\%: 30\%), F3 (80\%: 20\%), and F0 (100\% wheat flour) as the control group. The best formula of mangrove and soybean cookies was F2 with average energy 479.44 $\mathrm{kcal} / 100 \mathrm{~g}$, protein $11.70 \mathrm{~g} / 100 \mathrm{~g}$, fat $23.93 \mathrm{~g} / 100 \mathrm{~g}$, carbohydrate $54.31 \mathrm{~g} / 100 \mathrm{~g}$, zinc 2.68 $\mathrm{mg} / 100 \mathrm{~g}$, iron $6.72 \mathrm{mg} / 100 \mathrm{~g}$, calcium $659.03 \mathrm{mg} / 100 \mathrm{~g}, \mathrm{HCN} 1.77 \mathrm{ppm}$, and tannin $101.9 \mathrm{mg} / 100 \mathrm{~g}$. The best cookie formulation that met the SFP quality requirements was F2, with a composition of $70 \%$ mangrove fruit flour and $30 \%$ soy flour.
\end{abstract}

\section{Introduction}

Nutritional needs are essential for growth and development in infants and toddlers. Growth and development which are not optimal can cause children to experience stunting. Stunting is defined as, standard deviations (SDs) and the median height-for-age (HAZ), a measure based on a comparison of a child's height $(\mathrm{cm})$ and age (months) to the WHO standard (Ministry of Health of the Republic of Indonesia, 2016). Stunting in toddlers is a manifestation of chronic nutritional deficiencies that occur in the first thousand days of life from the fetus until two years of age, which results in children's linear growth failure (Leroy et al., 2014).

The intake of micronutrients, such as fibre, zinc, iron, and calcium contribute to growth. Physiologically, zinc increases during rapid growth due to DNA replication, DNA transcription, and endocrine function. Inadequate iron intake disrupts children's growth and development; if it occurs chronically, it can cause stunting. Adequate iron intake is required to form red blood cells in the bone marrow. Calcium regulates the activity of hormones and growth factors. Lack of calcium during the growth period results in disruption of growth (Ministry of Health of the Republic of Indonesia, 2016). Dietary fibre affects mineral absorption. Various types of dietary fibre could inhibit the intake of calcium, iron, zinc, and magnesium. One of them is lignin, which has a mineral binding function.

Based on basic health research data (Riskesdas), in 2018 , the stunting prevalence in Indonesia was $30.8 \%$ (Ministry of Health of the Republic of Indonesia, 2018b). One of the 100 cities that have become the priority for stunting management by the Indonesian government is Demak, with a stunting incidence rate of $50.28 \%$ (Tim Nasional Percepatan Penanggulangan Kemiskinan, 2017).

One of the efforts to help fulfilling children's nutritional adequacy under five is by using the Supplementary Feeding Programs (SFPs). SFPs quality requirements for toddlers contain at least $400 \mathrm{kcal}, 8-12$ grams of protein, and 10-18 $\mathrm{g}$ of fat (The Regulation from Ministry of Health of the Republic of Indonesia, 2016). The pattern of food diversification can be made by diversifying local food ingredients such as mangroves 
in Demak because they are available in large quantities.

Mangrove (Bruquiera gymnorrhiza) fruit can be used as a food source because it contains relatively high energy and carbohydrates (Handayani, 2018). Unfortunately, mangroves have compounds that are harmful to the body, such as HCN and tannins, which can inhibit nutrient absorption. Therefore, the level of use must be lowered before it is processed into food (Sulistyawati et al., 2012). HCN and tannins are volatile substances. Treatments such as repeated boiling and soaking can reduce the $\mathrm{HCN}$ and tannin content to a safe limit for consumption (Setianingsih, 2016). Tannins become carcinogenic substances when consumed in an excessive amount. The safe limit for tannins' food ingredients is $560 \mathrm{mg} / \mathrm{kg} /$ body weight/day (Setianingsih, 2016). In the body, HCN can interfere with the cytochrome-oxidase enzyme, which stimulates respiratory reactions in the aerobic organism. Therefore, the body can only tolerate HCN levels of less than 50 ppm (Baskin and Brewer, 2010).

The content in $100 \mathrm{~g}$ of mangrove fruit flour is 371 calories, $81.9 \%$ carbohydrates, $5.5 \%$ protein, and $0.23 \%$ fat (Mulyatun, 2018). The mineral content of mangrove fruit flour is $2948 \mathrm{ppm}$ calcium, $12 \mathrm{ppm}$ zinc, and 53 ppm iron. The high carbohydrate and energy content are suitable to use as food for the manufacture of SFPs products. Energy fulfilment in stunting children serves to improve their growth process (Adani and Nindya, 2017). However, the protein content in mangroves is relatively low, so it is necessary to combine them with other food ingredients containing protein sources to complement each other's nutritional content, one of which comes from soybeans.

Soybean (Glycine max), one of the local food protein sources, is readily available and relatively cheap. One hundred grams of soybeans contain 19.94\% fat, 34.95\% protein, and 29.94\% carbohydrates (Damanik et al., 2018). The mineral content in $100 \mathrm{~g}$ of dry soybeans is $10 \mathrm{~g}$ of insoluble fibre, $276 \mathrm{mg}$ of calcium, $16 \mathrm{mg}$ of iron, and $4.8 \mathrm{mg}$ of zinc. The protein and amino acid content in soybeans are higher than other beans, for example, kidney beans (Audu and Aremu, 2011; Pangastuti et al., 2013). The quality and quantity of adequate protein intake can function as Insulin Growth Factor 1 (IGF-1), a mediator of growth hormone and bone matrix formation. The fulfilment of protein intake in stunting children can help to repair linear growth disorders (Khairy et al., 2013). Soybean contains 102 $\mathrm{mg} / \mathrm{g}$ leucine (Damanik et al., 2018). Leucine plays a role in regulating bone growth to help correct linear growth disorders in stunted children (Semba et al., 2016).
The combination of mangrove fruit flour and soybean can create an additional food product for toddlers in the form of cookies. Cookies are an ideal snack full of nutrition and are widely consumed by all groups.

An analysis of nutritional content is necessary before the cookies are made on a large scale and given to children. This study aimed to determine the nutritional content, including the analysis of energy, carbohydrates, protein, fat, moisture, and ash content, and crude fibre, zinc, iron, and calcium mineral content. Apart from that, an anti-nutritional substance test was also carried out against $\mathrm{HCN}$ and tannin content to ensure food safety. An organoleptic quality test determines consumers' SFP preferences. Lastly, this research aimed to determine the best formulation of mangrove and soy cookies by considering all variables.

\section{Materials and methods}

\subsection{Study design and sample}

The research design used in this study was a randomized design with one factor. The percentages of mangrove and soybean flour used were 60:40\%, 70:30\%, and $80: 20 \%$. Table 1 shows the cookies' composition of mangrove and soybean flour. The main ingredients' nutritional value was calculated using the 2007 Nutrisurvey application and adjusted for the percentage of mangrove fruit flour and soybean flour that could meet SFPs specifications according to Minister of Health Regulation number 51 of 2016, which contains a minimum of $400 \mathrm{kcal}, 8-12 \mathrm{~g}$ of protein and 10-18 grams of fat (The Regulation from Ministry of Health of the Republic of Indonesia, 2016).

\subsection{Mangrove fruit flour preparation}

Lindur was the mangrove fruit processed into flour in this study (Bruquiera gymnorrhiza). The fruit was quite ripe, characterized by dark green, purplish colour, soft texture, $15-30 \mathrm{~cm}$ long and 1-2 cm wide (Sudirman et al., 2014). Mangrove flour was made by weighing the mangrove fruit first, then boiling it for $2 \times 15 \mathrm{mins}$, adding $15 \%$ rubbing ash to the second boiling session, then peeling it. After boiling, the mangrove fruit was soaked for 48 hrs by replacing the soaking water every 6 hrs (Perdana et al., 2012; Ayu et al., 2019). The soaked mangrove fruit was then dried for $48 \mathrm{hrs}$ in the scorching sun (Amalia et al., 2016; Amin et al., 2018). After drying, it was mashed with a grinding machine and sieved with an 80-mesh sieve (Sulistyawati et al., 2012).

\subsection{Cookies production}

The process started by homogenizing butter, 
Table 1. Formulation of cookies from mangrove fruit flour and soybean flour

\begin{tabular}{lcccc}
\hline \multicolumn{1}{c}{ Materials/Formulation } & $\begin{array}{c}\mathrm{F} 0 \\
(100 \%)\end{array}$ & $\begin{array}{c}\mathrm{F} 1 \\
(60: 40 \%)\end{array}$ & $\begin{array}{c}\mathrm{F} 2 \\
(70: 30 \%)\end{array}$ & $\begin{array}{c}\mathrm{F} 3 \\
(80: 20 \%)\end{array}$ \\
\hline Plain Flour (\%) & 40 & 0 & 0 & 0 \\
Mangrove Fruit Flour (\%) & 0 & 24 & 28 & 32 \\
Soybean Flour (\%) & 0 & 16 & 12 & 8 \\
Butter (\%) & 10 & 10 & 10 & 10 \\
Margarine (\%) & 10 & 10 & 10 & 10 \\
Egg (\%) & 12 & 12 & 12 & 12 \\
Refined Sugar (\%) & 18 & 18 & 18 & 18 \\
Milk (\%) & 10 & 10 & 10 & 10 \\
Total (\%) & 100 & 100 & 100 & 100 \\
\hline
\end{tabular}

margarine, milk, sugar powder, egg, and different types of flour according to the formula. After blending, the dough was shaped flat and round, then baked in an oven at $150^{\circ} \mathrm{C}$ for 15 mins.

\subsection{Organoleptic test}

Colour, taste, aroma, and texture of mangrove fruit and soy cookies as organoleptic test parameters were evaluated using 4 hedonic scale ratings from 1 (dislike), 2 (moderately like), 3 (like), and 4 (extremely like) (Ramadhan et al., 2019). Panellists who evaluated the organoleptic test were 30 trained panellists from seventhsemester students of the Nutrition Science Study Program of Universitas Diponegoro (Negara et al., 2016).

\subsection{Determination of nutrition content and nutrition absorption inhibiting agents}

The analysis of nutrition content and nutrition absorption inhibiting agents were carried out twice $(\mathrm{r}=$ 2) (Horwitz, 2005).

\subsubsection{Determination of protein}

Protein was analysed using the Kjeldahl method. The crushed cookies sample was accurately weighed and placed in a flask. Then it was added $\mathrm{Li}_{2} \mathrm{SO}_{4}, \mathrm{CuSO}_{4}$, and $\mathrm{H}_{2} \mathrm{SO}_{4}$. The solution was heated in a flask while being shaken every 10 mins for 75 mins. After the solution had cooled, it was transferred into a round bottom flask. The solution was added to distilled water and $\mathrm{NaOH}$. The solution was then distilled and collected in an Erlenmeyer that had $\mathrm{H}_{3} \mathrm{BO}_{3}$ and BCG-MR indicator. The results were titrated into $\mathrm{HCl}$ until the solution turned pink in colour.

\subsubsection{Determination of fat}

The fat was analysed by the Soxhlet method. The sample was placed in a flask and oven-dried at $105^{\circ} \mathrm{C}$ for 30 mins. Then, it was cooled in a desiccator for 15 mins, then weighed and placed on filter paper bundled with fatfree cotton. The sample was placed into the Soxhlet extraction device while fat was solvent in a flask. The extraction process lasted for 3-4 hrs. Then it was distilled and oven-dried at $105^{\circ} \mathrm{C}$ until its weight was constant. After the sample was cooled in a desiccator for 15-30 mins, the weighing was repeated.

\subsubsection{Determination of moisture}

The porcelain dish was heated at $105^{\circ} \mathrm{C}$ for $30 \mathrm{mins}$ and cooled in a desiccator before weighing. A $2 \mathrm{~g}$ sample was weighed and placed in a porcelain dish, and heated at $105^{\circ} \mathrm{C}$ for $6 \mathrm{hrs}$. After the sample had cooled in the porcelain dish in the desiccator, the weighing process was repeated until the sample reached a constant weight.

\subsubsection{Determination of ash}

The porcelain dish was heated for 30 mins at $105^{\circ} \mathrm{C}$ and then allowed to cool before weighing. A $2 \mathrm{~g}$ sample was placed in a porcelain dish and burned until there was no smoke. The ashing process was conducted in a furnace for $60 \mathrm{mins}$ at $550-600^{\circ} \mathrm{C}$. Then, the sample was cooled in a porcelain dish in a desiccator before weighing. The process was repeated until the sample had constant weight.

\subsubsection{Determination of carbohydrate and energy}

Carbohydrate analysis was conducted using a different method. The carbohydrate content was obtained by subtracting $100 \%$ with a percentage of protein, fat, moisture, and ash content. Total calories were obtained by converting protein, fat, and carbohydrate into calories and summing them up.

\subsubsection{Determination of crude fibre}

The sample was dried in an oven at $105^{\circ} \mathrm{C}$ till a constant weight was obtained. After the sample had cooled in a desiccator, $1 \mathrm{~g}$ of the sample was grounded and $\mathrm{H}_{2} \mathrm{SO}_{4}$ was added until it reached a volume of 150 $\mathrm{mL}$ and $n$-octanol was added as an antifoam agent. It was boiled for 30 mins, connected to a vacuum, rinsed with $30 \mathrm{~mL}$ hot deionized water three times, and then connected to compressed air, stirred each time rinsing 
took place. Then, $150 \mathrm{~mL}$ preheated $\mathrm{KOH}$ and an antifoam agent were added and boiled for 30 mins, filtered, and rinsed with $30 \mathrm{~mL}$ hot deionized water twice. Afterwards, it was rinsed with $30 \mathrm{~mL}$ cold deionized water. The rinsing was continued three times with $25 \mathrm{~mL}$ acetone and stirred by compressed air each time. The crucible was removed and weighed after ovendrying at $105^{\circ} \mathrm{C}$ for 60 mins until a constant weight was obtained.

\subsubsection{Determination of calcium}

A $10 \mathrm{~mL}$ sample was placed in a flask then added to $50 \mathrm{~mL}$ of distilled water and $10 \mathrm{~mL}$ of ammonium oxalate solution. The solution was made slightly alkaline by adding dilute ammonia. Then, it was made slightly acidic by adding a few drops of acetic acid until the colour of the solution was pink. It was boiled and left to rest for $4 \mathrm{hrs}$. The solution was filtered using Whatman paper No. 42 and rinsed several times with distilled water. The precipitate was transferred to another flask then rinsed and dissolved with hot sulfuric acid. The solution that was still in a hot state was titrated with a standard solution of $\mathrm{KMnO}_{4} 0.1 \mathrm{~N}$ until the first pink solution was formed and did not disappear for $15 \mathrm{~s}$. Calcium content was calculated based on the volume of the $\mathrm{KMnO}_{4}$ standard solution used for titration.

\subsubsection{Determination of iron, $H C N$, tannin}

Five grams of the sample were dissolved with $2 \mathrm{M}$ of $\mathrm{HCl}$. The solution was filtered and mixed with $\mathrm{KSCN}$. The absorbance of the solution was measured from the absorbance value that appears on the spectrophotometer compared to the standard.

\subsection{Statistical analysis}

The normality of data distribution was tested by the Shapiro-Wilk method. The total energy, protein, carbohydrates, water content, HCN, tannins, crude fibre, zinc, iron, and calcium content were analysed using One Way ANOVA followed by the Bonferroni test for normal distribution data. The fat, ash content, and organoleptic test data were analysed using the Kruskal Wallis test followed by the Mann-Whitney Test for irregular distribution data to determine the apparent difference between treatments.

\subsection{Determination of the selected formula}

The best formulation was determined by considering the value of nutritional content (energy, protein, fat, carbohydrate, moisture, and ash content), HCN content, tannins, and organoleptic parameters (colour, taste, aroma, and texture) using the Effectiveness Index ( $D e$ Garmo) (De Garmo et al., 1995). The variable weight was determined with a scale of $0-1$ for each parameter based on priority subsequently by determining the effectiveness value $(\mathrm{Ne})$ on each variable. Finally, the yield value $(\mathrm{Nh})$ was calculated, and the best formulation had the highest score.

\section{Results}

\subsection{Nutritional content}

Based on the proximate analysis, the highest nutritional content in mangrove fruit flour was carbohydrate content as presented in Table 2 . A total of 1 $\mathrm{kg}$ fresh mangrove fruit produced roughly $500 \mathrm{~g}$ of mangrove fruit flour. The HCN and tannin content was still within safe limits for consumption.

Table 2. Nutritional content in $100 \mathrm{~g}$ of mangrove fruit and $100 \mathrm{~g}$ of mangrove fruit flour

\begin{tabular}{lcc}
\hline Component & Mangrove Fruit & Mangrove Fruit Flour \\
\hline Energy (kcal) & 144.93 & 349.28 \\
Protein $(\mathrm{g})$ & 2.04 & 5.34 \\
Fat $(\mathrm{g})$ & 0.43 & 0.64 \\
Carbohydrate $(\mathrm{g})$ & 33.22 & 80.56 \\
Water Content $(\%)$ & 62.99 & 12.31 \\
Ash Content $(\%)$ & 1.32 & 1.17 \\
HCN (ppm) & 5.03 & 4 \\
Tanin $(\mathrm{mg})$ & 100.9 & 101.9 \\
\hline
\end{tabular}

The analysis of the nutritional content of cookies with mangrove fruit flour and soybeans was presented in Table 3. The energy $(p=0.020)$, protein $(p=0.001)$, carbohydrates $(p<0.000), \mathrm{HCN}$, and tannins were significantly different. However, there was no difference in moisture ( $p=0.83)$ and HCN content $(p=1.54)$.

The energy content of the cookies F0, F1, F2, and F3 met the SFPs quality requirements, which contained at least 400 kcal. Protein content in F0, F2, and F3 met the quality requirements, but F1 exceeded the specified quality requirements. The fat content and moisture content in all cookies exceeded the SFPs quality requirements. The fibre content in the F1-F3 formulation cookies exceeded the SFPs quality requirements. Zinc content in F0, F1, and F2 met the SFPs quality requirements while $\mathrm{F} 3$ exceeded the requirement.

\subsection{Organoleptic test}

An organoleptic test to determine consumers' acceptance of cookies made from mangrove fruit flour and soybeans acceptance involved assessing the flavour, aroma, appearance, and texture. Based on Table 4, the statistical test results showed significant differences in the colour, taste, aroma, and texture of the product. On the colour indicator, a darker brown intensity of the cookies was more preferred by panellists (Dhinendra et 
Table 3. Results of nutritional content analysis of cookies made from mangrove fruit flour, and soybeans in $100 \mathrm{~g}$

\begin{tabular}{lcccccc}
\hline \multicolumn{1}{c}{ Formula } & F0 & F1 & F2 & F3 & $P$ & Cut off $^{1}$ \\
\hline Energy (kcal) & $462.66 \pm 4.71^{\mathrm{a}}$ & $483.39 \pm 5.35^{\mathrm{b}}$ & $479.44 \pm 1.37^{\mathrm{a}}$ & $482.28 \pm 3.68^{\mathrm{a}}$ & $0.020^{*}$ & Min.400 \\
Protein (g) & $8.99 \pm 0.24^{\mathrm{a}}$ & $13.22 \pm 0.62$ & $11.70 \pm 0.10^{\mathrm{c}}$ & $10.57 \pm 0.14^{\mathrm{d}}$ & $0.001^{*}$ & $8-12$ \\
Fat (g) & $20.30 \pm 0.30$ & $24.92 \pm 0.59$ & $23.93 \pm 0.28$ & $24.75 \pm 0.30$ & $0.112^{* *}$ & $10-18$ \\
Carbohydrate (g) & $60.98 \pm 0.27^{\mathrm{a}}$ & $51.55 \pm 0.62^{\mathrm{b}}$ & $54.31 \pm 0.40^{\mathrm{c}}$ & $54.32 \pm 0.09^{\mathrm{d}}$ & $0.00^{*}$ & - \\
Water content (\%) & $8.36 \pm 0.83$ & $8.04 \pm 0.60$ & $7.88 \pm 0.14$ & $8.29 \pm 0.56$ & $0.83^{*}$ & Max.5 \\
Ash content (\%) & $1.36 \pm 0.02$ & $2.26 \pm 0.00$ & $2.18 \pm 0.00$ & $2.08 \pm 0.02$ & $0.080^{* *}$ & - \\
HCN (ppm) & $-* * *$ & $2.87 \pm 0.75$ & $1.77 \pm 0.28$ & $1.75 \pm 0.06$ & $0.154^{*}$ & 502 \\
Tanin (mg) & $-* * *$ & $101.0 \pm 0.00^{\mathrm{a}}$ & $101.9 \pm 0.00^{\mathrm{b}}$ & $99.2 \pm 0.00^{\mathrm{c}}$ & $0.006^{*}$ & 5603 \\
Rough Fibre (g) & $3.29 \pm 0.47^{\mathrm{a}}$ & $5.90 \pm 0.39^{\mathrm{b}}$ & $6.74 \pm 0.08^{\mathrm{c}}$ & $7.88 \pm 0.29^{\mathrm{d}}$ & $0.00^{*}$ & Max.5 \\
Zinc (mg) & $4.92 \pm 0.54^{\mathrm{a}}$ & $3.07 \pm 0.33^{\mathrm{b}}$ & $2.68 \pm 0.03^{\mathrm{b}}$ & $3.03 \pm 0.99^{\mathrm{b}}$ & $0.001^{*}$ & $2.0-3.75$ \\
Iron (mg) & $3.93 \pm 0.92^{\mathrm{a}}$ & $6.02 \pm 0.46^{\mathrm{b}}$ & $6.72 \pm 0.43^{\mathrm{b}}$ & $8.32 \pm 0.79^{\mathrm{c}}$ & $0.00^{*}$ & $4.0-7.5$ \\
Calcium (mg) & $407.97 \pm 19.24^{\mathrm{a}}$ & $534.27 \pm 14.87^{\mathrm{b}}$ & $659.03 \pm 26.92^{\mathrm{c}}$ & $735.97 \pm 25.51^{\mathrm{d}}$ & $0.00^{*}$ & $225-450$ \\
\hline
\end{tabular}

Values are presented as mean \pm SD. Values with different superscript letters within the same row are significantly different $(\mathrm{p}<0.05)$.

*test with One Way ANOVA, **test with the Kruskal Wallis test, *** test for HCN and tannins against F0

${ }^{1}$ Peraturan Menteri Kesehatan Republik Indonesia (2016)

${ }^{2}$ Baskin and Brewer (2010)

${ }^{3}$ Setianingsih (2016)

Table 4. Organoleptic test results for cookies of mangrove fruit flour and soybeans

\begin{tabular}{|c|c|c|c|c|}
\hline \multirow{2}{*}{ Formula } & \multicolumn{4}{|c|}{ Receiving Power (Mean \pm SD) } \\
\hline & Colours & Taste & Aroma & Texture \\
\hline F0 & $\begin{array}{c}2.87 \pm 0.73^{\mathrm{a}} \\
(\text { Like) }\end{array}$ & $\begin{array}{c}3.60 \pm 0.56^{\mathrm{a}} \\
\text { (Really Like) }\end{array}$ & $\begin{array}{c}3.57 \pm 0.56^{\mathrm{a}} \\
\text { (Really Like) }\end{array}$ & $\begin{array}{c}3.63 \pm 0.55^{\mathrm{a}} \\
\text { (Really Like) }\end{array}$ \\
\hline $\mathrm{F} 1$ & $\begin{array}{c}3.10 \pm 0.48^{\mathrm{b}} \\
(\text { Like })\end{array}$ & $\begin{array}{c}2.60 \pm 0.62^{\mathrm{b}} \\
(\mathrm{Like})\end{array}$ & $\begin{array}{c}2.73 \pm 0.74^{b} \\
(\text { Like })\end{array}$ & $\begin{array}{c}2.67 \pm 0.60^{\mathrm{b}} \\
(\text { Like })\end{array}$ \\
\hline $\mathrm{F} 2$ & $\begin{array}{c}2.97 \pm 0.66^{\mathrm{c}} \\
(\mathrm{Like})\end{array}$ & $\begin{array}{c}2.40 \pm 0.49^{\mathrm{c}} \\
\text { (Rather Like) }\end{array}$ & $\begin{array}{c}2.50 \pm 0.63^{\mathrm{c}} \\
\text { (Rather Like) }\end{array}$ & $\begin{array}{c}2.23 \pm 0.60^{\mathrm{c}} \\
\text { (Rather Like) }\end{array}$ \\
\hline F3 & $\begin{array}{c}3.63 \pm 0.62^{\mathrm{d}} \\
\text { (Really Like) }\end{array}$ & $\begin{array}{c}2.00 \pm 0.74^{\mathrm{d}} \\
\text { (Rather Like) }\end{array}$ & $\begin{array}{c}2.40 \pm 0.67^{\mathrm{d}} \\
\text { (Rather Like) }\end{array}$ & $\begin{array}{c}1.60 \pm 0.67^{\mathrm{d}} \\
\text { (Dislike) }\end{array}$ \\
\hline$P$ & $0.002 *$ & $0.00 *$ & $0.00 *$ & $0.00 *$ \\
\hline
\end{tabular}

Values are presented as mean \pm SD. Values with different superscript letters within the same row are significantly different $(\mathrm{p}<0.05) .{ }^{*}$ test with the Krusal Wallis Test

Table 5. Calculation results for determining the best formulation

\begin{tabular}{lcccc}
\hline Formula/ Yield Value (Nh)* & F0 & F1 & F2 & F3 \\
\hline Energy & 0 & 0.1852 & 0.1499 & 0.1753 \\
Protein & 0 & 0.2602 & 0.1667 & 0.0972 \\
Fat & 0.1481 & 0 & 0.0317 & 0.0054 \\
Carbohydrate & 0.1296 & 0 & 0.0379 & 0.0381 \\
Water Content & 0 & 0.0741 & 0.1111 & 0.0162 \\
Ash Content & 0 & 0.037 & 0.0337 & 0.0296 \\
HCN & 0 & 0 & 0.0909 & 0.0926 \\
Tanin & 0 & 0.0247 & 0 & 0.0741 \\
Organoleptic Quality & 0.0556 & 0.0206 & 0.0067 & 0 \\
\hline Total of Yield Value $(\mathrm{Nh})$ & 0.3333 & 0.6017 & 0.6287 & 0.5285 \\
\hline
\end{tabular}

*result value $(\mathrm{Nh})$ is obtained from the deGarmo Effectiveness Index calculation

al., 2015). The taste of cookies favoured by the panellists was sweet, and the favoured level decreased with the bitter after-taste in cookies (Rosyadi et al., 2014). Cookies have a distinctive aroma, which was very fragrant. The panellists preferred less of the peculiar aroma of mangrove fruit and the unpleasant aroma of soybeans in cookies. (Fajri et al., 2013). The panellists preferred the cookies' crunchy texture over a hard texture (Sarofa and Yulistiani, 2013).

\subsection{Determining the best formulation}

Based on Table 5, calculation results for determining the best formulation, F2 was the best formulation with a 
composition of $70 \%$ mangrove fruit flour and $30 \%$ soy flour. The selected formulation was based on the nutritional content and the panellists' level of preference in the organoleptic test. Overall, the nutritional content in F2 met the Supplementary Feeding (SF) quality requirements according to Ministry of Health Regulation number 51 of 2016 . However, the fat and water content in the cookie products still exceeded the predetermined quality requirements.

\section{Discussion}

\subsection{Nutritional content of mangrove fruit and mangrove} fruit flour

The study results indicated that the levels of $\mathrm{HCN}$ and tannins in cookies were safe for human consumption. HCN and tannins were volatile substances. Based on previous research, treatments such as repeated boiling and soaking could reduce the HCN and tannin content in mangroves (Baskin and Brewer, 2010). Reducing the levels of $\mathrm{HCN}$ and tannins could be carried out during the pre-treatment of the flour process. In this study, boiling for $2 \times 15$ mins at a temperature of $100^{\circ} \mathrm{C}$ and immersion for $48 \mathrm{hrs}$ resulted in a tannin content of $101.9 \mathrm{mg} / \mathrm{kg}$ and $4 \mathrm{ppm} \mathrm{HCN}$.

The boiling process could reduce $\mathrm{HCN}$ levels because HCN experienced evaporation. The HCN boiling point was low, at $26^{\circ} \mathrm{C}$, and it evaporated easily (Sulistyawati et al., 2012). The repeated soaking process led to the slow degradation of the HCN where it would be dissolved in the bathwater. After that, the drying process after soaking the rest of the $\mathrm{HCN}$ would evaporate (Ayu et al., 2019).

The addition of ash in the boiling process served to inhibit the metabolism rate of tannin. Alkalis could hydrolyse tannins. Rubbing ash was an alkaline group because it contained $\mathrm{KOH}$. Tannins would break down into glucose and gallic acid when heated (Ayu et al., 2019). The effect of rubbing ash in boiling resulted in toxic substances, including tannins bound to the ash (Perdana et al., 2012).

The soaking process could reduce the levels of tannins found in mangroves. Tannins had polar properties that could dissolve in water (Dhinendra et al., 2015). In the soaking process, a diffusion process occurred by dissolving the fruit's remaining substances. This was indicated by the water condition that changed colour to brown or foamy (Amalia et al., 2016). Without immersion treatment, the resulting mangrove fruit flour would have high tannins to be dangerous for consumption. High levels of tannins would also affect the taste, giving food a bitter taste (Hagerman, 2010).

\subsection{Nutrition content of mangrove and soy cookies}

The energy in all cookie formulations fluctuated from F1 to F3. The energy in cookies was influenced by other nutrients such as protein, fat, and carbohydrates. Cookies formulated with mangrove fruit flour and soy flour had higher energy than control cookies because cookies' protein and fat content increased. The increase in protein and fat in formulated cookies came from the ingredients' fat and protein content. The energy content of cookie products met the SF quality requirements, which contained a minimum of $400 \mathrm{kcal}$ of energy (the Regulation from the Ministry of Health of the Republic of Indonesia, 2016).

The protein test results showed that the addition of soy flour could increase the product's protein content. The protein source in making cookies mostly came from soy flour, which had high protein content (Damanik et $a l ., 2018)$. The low protein content in cookies was caused by the low levels of adding soy flour to the product. The lowest protein content was in cookies with $100 \%$ wheat flour. This was because the protein content in wheat flour $(9 \mathrm{~g} / 100 \mathrm{~g})$ was lower than soy flour (34.9 $\mathrm{g} / 100 \mathrm{~g}$ ) (Aini and Wirawani, 2013).

In previous research on the manufacture of cookies, the substitution of canna and soy flour showed that the addition of soy flour by $75 \%$ had a protein content of $28.12 \mathrm{~g} / 100 \mathrm{~g}$ (Lestaria et al., 2018). In other studies, the substitution of $25 \%$ soy flour in the manufacture of foods to replace breast milk (MP-ASI) biscuits could increase protein content by up to $10.02 \%$ (Aini and Wirawani, 2013).

Based on the SF quality requirements, the protein content in F0, F2, and F3 cookies met the requirements of 8-12 g/100 g (the Regulation from the Ministry of Health of the Republic of Indonesia, 2016). F1 protein content excessed the SFP's quality requirement standards due to adding $40 \%$ soy flour. Adequacy of protein was required for the growth process, but excess protein consumption would increase fat mass in children (Aini and Wirawani, 2013).

Inversely proportional to the protein content, the carbohydrate content in cookies increased with increasing levels of the mangrove fruit flour. The increase in carbohydrates occurred because the carbohydrate content in mangrove fruit flour was higher $(80.56 \mathrm{~g} / 100 \mathrm{~g})$ compared to wheat flour $(77.3 \mathrm{~g} / 100 \mathrm{~g})$ and soy flour $(42.64 \mathrm{~g} / 100 \mathrm{~g}$ ) (the Ministry of Health of the Republic of Indonesia, 2018a). Cookies with the highest carbohydrate content had the highest amount of mangrove flour.

This study's results were consistent with research on 
the manufacture of curisi fish nuggets and catfish meatballs. The carbohydrate content in food products substituted by mangrove fruit flour increased with this flour (Dhinendra et al., 2015; Alno et al., 2018). The carbohydrate content at F0 was higher than other cookie formulations because it only used wheat flour, while others used mangrove fruit flour and soy flour. Soy flour had the lowest carbohydrate content when compared to mangrove flour and wheat flour. Thus, it could not increase the carbohydrate content in cookies (Fajri et al., 2013). The fat content in cookies fluctuated in the formulation group. The highest fat content was in F1 with the addition of $40 \%$ soy flour. Also, the fat content in cookies exceeded the predetermined SF quality requirements, which was $10-18 \mathrm{~g} / 100 \mathrm{~g}$ (the Regulation from the Ministry of Health of the Republic of Indonesia, 2016).

This study showed a higher fat content than previous studies on the manufacture of fish nuggets substituted by mangrove fruit flour. The increase in fat content in the product would increase along with the additional mangrove fruit flour (Amalia et al., 2016).

The high-fat content in cookies could be caused by the fat source ingredients used and the less optimal cookie processing. The cookies were baked at $150^{\circ} \mathrm{C}$ for 15 mins. In general, after processing, the fat contained in the cookies will break down. The degree of fat breakdown varied greatly depending on the temperature used and the length of processing time. The higher the temperature and the longer the roasting process, the fat content would decrease. This was because fat is not heat resistant, it would melt and even evaporated (volatile), which was caused by the breakdown of the fat components into volatile products such as aldehydes, ketones, alcohols, and hydrocarbons which greatly affected the formation of flavour (Heldman, 2012; Sundari et al.,2015).

This research showed that butter, margarine, egg yolk, and soy flour contribute to cookies' fat content. Soy flour was known to have a high-fat content. Fat is needed to make cookies as a dough softener, binder, and shortening to make food more savoury (Jacob and Leelavathi, 2007). Mangrove fruit flour had a low amylopectin content, making it difficult for the dough to blend and be sticky. Large amounts of butter and margarine could help bind the dough (Dhinendra et al., 2015).

The water content in all formulations exceeded the predetermined SF quality requirements, a maximum of $5 \%$ (the Regulation from the Ministry of Health of the Republic of Indonesia, 2016). The process could influence the cause of the high moisture content in cookies and the materials used. In baking cookies, it only took 15 mins with a temperature of $150^{\circ} \mathrm{C}$. Thus, the reduction in water content in cookies was not optimal. The higher the processing temperature and the longer the processing time, the less water content was found in the material (Nilasari et al., 2017). The heat treatment process caused a gelatinization process in which the starch granule molecules absorbed water from the material. The processing process was also related to the evaporation of water on the material. The longer and higher processing temperature could cause more water to evaporate. Evaporation occurred because the water vapour pressure in the material was greater than the water vapour in the air, so the mass transfer of water from the material to the air occurred (Heldman, 2012).

The content of mangrove fruit flour had high water content. Mangrove fruit flour had a high water content because mangroves grew in aquatic habitats to have sufficient water reserved to survive (Amin et al., 2018). The increase in water content was also caused by mangrove fruit flour's high fibre content, which resulted in a large amount of bound water (Rosyadi et al., 2014). In the flour-making process, efforts had been made to reduce the mangroves' moisture content during drying. However, direct drying with sunlight had not resulted in a maximum reduction in moisture content.

Previous research on the substitution of mangrove fruit flour in catfish biscuits suggested that mangrove fruit flour could increase the carbohydrate, ash, and water content and reduce protein and fat content (Rahmaningsih et al., 2016). In this study, the water content in biscuits was classified as low and met the Indonesian national biscuit standard of a maximum of $5 \%$. The difference in water content in the final product was influenced by the difference in water content in the type of flour used.

The water content in the formulated cookies exceeded the specified quality requirements because making mangrove fruit flour was not optimal. During the drying process, it only used direct sunlight, which caused the evaporation process to be less optimal. As a result, it still contained water. In previous research related to mangrove fruit flour manufacturing, the drying process using an oven at a temperature of $60^{\circ} \mathrm{C}$ for $7 \mathrm{hrs}$, resulting in a moisture content that was $11.17 \%$ lower than this study in $12.31 \%$ (Ayu et al., 2019).

The ash content in a material indicated the presence of organic mineral content in the food material. Ash could describe the content of mineral elements contained in food products or ingredients. Besides that, it could also show the purity and cleanliness of the material (Hastuti and Afifah, 2019). The lowest ash content was 
in F0 cookies which used $100 \%$ wheat flour. The less ash content was in the product in mangrove fruit and soy flour cookies, the less soy flour was added. This was because soy flour was a mineral source (Okoye and Nkwocha, 2008). Soy flour contained minerals such as calcium, potassium, phosphorus, and iron (Damanik et al., 2018).

In the mangrove fruit flour and soybean cookies, the highest $\mathrm{HCN}$ content was in $\mathrm{F} 1$ with $60 \%$ mangrove fruit flour to the product. The HCN level decreased along with the addition of mangrove fruit flour to the cookie's product. Thus, F3 had the lowest HCN levels. This could be caused by the roasting process that alternated from $\mathrm{F} 1$ to F3 cookies so that the cookies baked last would receive heat accumulation from the previous roasting. The higher the temperature for roasting, the more the HCN content of the cookies would decrease. This was because HCN was a volatile compound due to heat (Sari and Astili, 2018). The HCN content in cookies was still within a safe limit for consumption of $<50 \mathrm{ppm}$ (Baskin and Brewer, 2010).

The highest tannin content in cookies was F2, while the lowest was F3. The percentage of mangrove fruit flour added and the cookies' baking process influenced the tannin content (Carica, 2015; Amalia et al., 2016). The lowest tannin content in F3 could be because of the oven temperature. The oven alternating from F1 to F3 results in heat accumulation on $\mathrm{F} 3$ roasting, resulting in a higher temperature on $\mathrm{F} 3$ roasting than the others so that the tannin compounds were more broken down. (Hawa et al., 2018). Tannins were chemical compounds belonging to the polyphenol group that could be hydrolysed into simpler compounds when they underwent a heating process (Liang and Yi, 2009).

\subsection{Mineral content of mangrove and soy cookies}

Cookies with the substitution of mangrove and soybean flour had higher crude fibre content than control cookies $(100 \%$ wheat flour). The increased crude fibre content was influenced by the composition of the flour used in making cookies. A crude fibre in the mangrove fruit flour was greater than wheat flour. The crude fibre content in wheat flour was $5.60 \%$, while in the mangrove fruit flour was $7.46 \%$ (Bashir et al., 2017). This was consistent with previous research, which suggested that the addition of mangrove fruit flour to the African catfish nuggets could increase crude fibre content (Mervina et al., 2012).

The crude fibre content in modified cookies had exceeded the SFP's quality requirement standard due to mangrove fruit flour which had higher crude fibre content than wheat flour in control cookies. Besides being able to have beneficial effects on health, there were detrimental effects on crude fibre if consumed in excess amounts. Crude fibre could bind to nutrients that could affect mineral balance. This could bind to cations such as calcium, zinc, and iron, causing deficiency of calcium, iron, zinc, copper, and magnesium due to the excessive amount of fibre in the diet, especially in young children (Clifford et al., 2015).

Iron was an important micronutrient for the body. Iron has several functions, energy metabolism, growth and development, the immune system, and the ability to learn (Sundari and Nuryanto, 2016). The iron content of cookies increased along with the addition of mangrove fruit flour. Based on the statistical test results, the highest iron content in cookies was found in F3 cookies, which showed that F3 cookies did not meet the SF quality requirements because iron levels exceeded the requirements $(>7.5 \mathrm{mg} / 100 \mathrm{~g})$. The composition of the ingredients used in making cookies influenced the increased iron levels. The iron content of mangrove and soybean flour used in F1, F2, and F3 cookies was higher than the wheat flour used in F0 cookies. The iron content in mangrove fruit flour was $53 \mathrm{ppm}(5.3 \mathrm{mg} / 100 \mathrm{~g})$, and soybean flour was $8.4 \mathrm{mg} / 100 \mathrm{~g}$, while wheat flour was $1.3 \mathrm{mg} / 100 \mathrm{~g}$. Several studies have shown that excess iron supplementation in toddler's results in slower growth and lower body weight. Excess iron intake could also reduce zinc absorption (Lönnerdal, 2017).

Calcium was a micronutrient that played an important role in children's linear growth. Lack of calcium in infants could cause rickets, while in children, a deficiency could result in stunted growth (Stuijvenberg et al., 2015). Calcium test results showed the addition of mangrove and soy flour could increase the calcium content of cookies. The lowest calcium content was found in control cookies which only used $100 \%$ wheat flour. The addition of calcium levels was influenced by the ingredients' composition, which was the calcium content of mangrove and soybean flour which were higher than wheat flour. The calcium of mangrove fruit flour was $2948 \mathrm{ppm}(294.8 \mathrm{mg} / 100 \mathrm{~g})$, and soy flour was $195 \mathrm{mg} / 100 \mathrm{~g}$, while wheat flour was only $22 \mathrm{mg} / 100 \mathrm{~g}$.

Based on SFP's quality requirements, the content of calcium cookies in F1, F2, and F3 did not meet the requirements because the levels exceeded the standard $(>450 \mathrm{mg} / 100 \mathrm{~g})$. A study showed that high calcium intake had no side effects in increasing the risk of hypercalcemia, hypercalciuria, or kidney stone symptoms in toddlers. Short-term studies showed that calcium could affect iron and zinc absorption but not in the long term (SCF (Scientific Committee on Food), 2003; European Food Safety Authority (EFSA), 2012). 
As a source of functional food, soybeans contained important components useful for health, including vitamins (vitamins $\mathrm{A}, \mathrm{E}, \mathrm{K}$, and several types of $\mathrm{B}$ vitamins) and minerals ( $\mathrm{K}, \mathrm{Fe}, \mathrm{Zn}$, and $\mathrm{P}$ ). The high mineral content in cookies with the substitution of mangrove fruit flour and soybean flour was influenced by the ash content contained in the materials used. Ash content was closely related to the mineral content in a food product. The largest ash content among mung bean flour, winged bean, and jack bean came from soybean flour. This was because soybeans were a high source of vitamins and minerals. The vitamins in soybeans were thiamine, riboflavin, niacin, and carotene. Soybeans were also a good source of minerals such as $\mathrm{Ca}, \mathrm{Fe}, \mathrm{Cu}, \mathrm{Mg}$, and $\mathrm{Na}$. Mangrove fruit flour had higher ash content than wheat flour. This also showed that the mineral content in mangrove fruit flour was higher than wheat flour. Also, in previous studies, extra soy flour could increase the ash content of food bars because soybeans were a high mineral source (Sandjaja, 2009; Jariyah et al., 2017; Amin et al., 2018).

\subsection{Organoleptic quality test for mangrove and soy cookies}

The panellists' assessment on the most preferred cookie colour parameter was F3 with $80 \%$ mangrove fruit flour. The brown colour of F3 captivated the panellists. The brown colour produced in the cookies came from the mangrove fruit flour colour (Amin et al., 2018).

Mangrove fruit flour had a brown colour, so the resulting product would also be brown. (Rosyadi et al., 2014). The brown colour produced by mangrove fruit flour came from the mangroves' tannin content (Amin et al., 2018).

The heating process at high temperatures could also cause a Maillard reaction between reducing sugars from starch and amino acids (primary amino groups) from proteins, resulting in the formation of a brown colour. This reaction occurred due to lysine and simple sugars in soy flour and skim milk (Tien and Fitriyono, 2010). F0 cookies had the lowest colour preference value by panellists because the F0 cookies used 100\% wheat flour, the final colour of the product was golden yellow. This colour lacked appeal to the panellists.

Based on the organoleptic test on taste, F1 cookies with the addition of $60 \%$ mangrove fruit flour and $40 \%$ soybean flour were the preferred cookies' formulation by panellists. The taste preference level decreased as the amount of mangrove fruit flour increased because it caused a bitter after-taste (Sudirman et al., 2014).
Mangrove fruit flour had a distinctive taste and was still less familiar to the panellists. The taste of mangrove fruit flour that was too thick could cover the flavours of the other ingredients. The bitter taste might come from the mangrove tannins. In this study, efforts have been made to reduce tannin levels by boiling and soaking in mangroves. Tannins were acidic polyphenol compounds that caused a bitter taste in mangrove fruit flour (Hagerman, 2010). Soy flour was also identical with a bitter taste (chalky flavour). Soybeans had an off-flavour in the form of a bitter taste caused by the presence of glycosides and isoflavone compounds in soybean seeds. Among these glycosides were soyasaponin and sapogenol (Purwanto and Hersoelistyorini, 2011). In making soy flour, efforts were made to reduce chalky flavours such as soaking and heating soybeans. However, soyasaponin compounds were relatively heat resistant, so that not all of them could be removed (Ginting and Antarlina, 2002). Research on making soy flour using the boiling method at $100^{\circ} \mathrm{C}$ for 5 mins could reduce soya saponin by $28.6 \%$ (Chaturvedi et al., 2012). The addition of sugar in making cookies from mangrove fruit flour and soybeans was one effort to reduce the final product's bitterness.

The most preferred cookie was F0 with $100 \%$ wheat flour, and the least preferred was F3 with the addition of $80 \%$ mangrove fruit flour and $20 \%$ soy flour. The aroma produced by cookies comes from the ingredients used, such as butter, margarine, sugar, milk, and eggs. In addition to the aroma produced from these ingredients, mangrove fruit flour and soybeans' aroma also affected the cookies' final aroma. The addition of a higher concentration of mangrove fruit flour reduces the panellists' preference. This is due to the unfamiliar aroma of mangrove fruit flour.

Mangrove fruit flour had a distinctive aroma. Thus, it could cover up the aroma of other ingredients used (Alno et al., 2018). Also, the addition of soy flour had a role in cookies' aroma. Soy flour had a distinctive aroma from soybeans (beany flavour). The lipoxygenase enzyme activity found in soybeans caused the unpleasant aroma due to the mixing of lipoxygenase in soybean fat when making soybean flour, which was when the soybean seeds broke during the peeling and refining process (Purwanto and Hersoelistyorini, 2011). The cause of the beany flavour in the flour was the less optimal process of making soybean flour and the method used (Yang et al., 2016). Efforts to reduce beany flavour were soaking by adding $0.25 \%$ sodium bicarbonate and boiling it at $100^{\circ} \mathrm{C}$ for 20 mins (Rajapakse, 2015).

Based on the organoleptic test results, the preference for the cookies' texture was lower when there was more 
mangrove fruit flour (Alno et al., 2018). The texture of the cookies would harden along with the increase in the amount of mangrove fruit flour. This was because the amylopectin content in mangrove fruit flour was lower than wheat flour (Amin et al., 2018).

Amylopectin played an important role in the formation of product elasticity. Amylopectin played a role in the formation of the physical properties of the product. The higher the amylopectin level was, the stickier the food material was, and vice versa (Dhinendra et al., 2015). In the mangrove and soybean flour cookies, the additional soy flour was inversely proportional to extra mangrove fruit flour. The concentration of adding soybean flour also affected the texture of the resulting product. The more soy flour was added, the crunchier the texture would be. Soy flour contained lecithin, which functioned as an emulsifier and bound water to improve the texture of the product to become crispier (Mervina et al., 2012).

\subsection{Determination of the best formulation}

Determination of the best formulation was done using the product effectiveness test with the De Garmo method. The selected formula's nutritional content was the basis for determining SF cookies' serving size for mangrove flour and soybeans. The serving size was calculated from the number of cookies needed to meet $1 / 3$ of a toddler's daily energy needs. The selected formula F2 contained energy as much as $479.44 \mathrm{kcal} / 100$ g, carbohydrates $54.31 \mathrm{~g} / 100 \mathrm{~g}$, protein $11.70 \mathrm{~g} / 100 \mathrm{~g}$, and fat $23.93 \mathrm{~g} / 100 \mathrm{~g}$.

Supplementary Feeding (SF) cookies' serving size for mangrove fruit flour and soybeans was 5 pieces (50 g) for children aged 7-11 months and 9 pieces $(90 \mathrm{~g})$ for children aged 12-36 months. This met 33-38\% RDA for energy, 31-32\% RDA for carbohydrates, 32-38\% RDA for protein, and $33-48 \%$ RDA for fat. Supplementary Feeding (SF) cookies could be used as a morning, afternoon, and evening snack.

\section{Conclusion}

The nutritional content, mineral substances, and HCN compounds and tannins in cookies have met the SFP quality requirements. However, the content of F1 protein, fat, and water exceeded the quality requirements. Crude fibre and calcium content in F1, F2, and F3 did not meet the quality requirements, but zinc content met SF quality requirements. The iron content in F1 and F2 met the SF quality requirements. The best cookie formulation that met the PMT quality requirements was F2, with a composition of $70 \%$ mangrove fruit flour and $30 \%$ soy flour.

\section{Conflict of interest}

The authors declare no conflict of interest.

\section{Acknowledgements}

The researchers are grateful to the Higher Education Applied Research and the Directorate of Research and Community Service Directorate General of Strengthening Research and Development of Ministry of Research, Technology and Higher Education to fund this study.

\section{References}

Adani, F.Y. and Nindya, T.S. (2017). Perbedaan asupan energi, protein, zink, dan perkembangan pada balita stunting dan non stunting. Amerta Nutrition, 1(2), 46 -51. https://doi.org/10.20473/amnt.v1i2.6225 [In Bahasa Indonesia].

Aini, N. and Wirawani, Y. (2013). Kontribusi MP-ASI biskuit tepung garut, kedelai dan ubi jalar kuning terhadap kecukupan protein, vitamin A, kalsium dan zink pada bayi. Journal of Nutrition College, 2(4), 458-466. https://doi.org/10.14710/jnc.v2i4.3727

Alno, M., Kurniawati, N. and Liviawat, E. (2018). Substitusi tepung daging buah lindur terhadap tingkat kesukaan bakso lele. Jurnal Perikanan dan Kelautan, 8(1), 66-78. https://doi.org/10.33512/ jpk.v8i1.3685 [In Bahasa Indonesia].

Amalia, U., Darmanto, Y.S., Sumardianto and Rianingsih, L. (2016). Chemical characteristics of fish nugget with mangrove fruit flour substitution. Aquatic Procedia, 7, 265-270. https:// doi.org/10.1016/j.aqpro.2016.07.037

Amin, M.N., Praledba, S.A., Hasan, M.N., Zakariya, Subekti, S., Saputra, E., Andriyono., Pramono, H. and Alamsyah, M.A. (2018). Physicochemical properties of Bruguiera gymnorrhiza flour (BGF). International Food Research Journal, 25(5), 18521857.

Audu, S.S. and Aremu, M.O. (2011). Effect of processing on chemical composition of red kidney bean (Phaseolus vulgaris L.) flour. Pakistan Journal of Nutrition, 10(11), 1069-1075. https:// doi.org/10.3923/pjn.2011.1069.1075

Ayu, M., Tamrin. and Hermanto. (2019). Pengaruh lama dan suhu pengeringan dalam pengolahan tepung buah mangrove jenis lindur (Bruguiera gymnorrhiza). Jurnal Sains dan Teknologi Pangan, 4 (1), 1879-1891. [In Bahasa Indonesia].

Bashir, K., Swer, T.L., Prakash, K.S. and Aggarwal, M. (2017). Physico-chemical and functional properties 
of gamma irradiated whole wheat flour and starch. LWT - Food Science and Technology, 76(Part A), 131-139. https://doi.org/10.1016/j.lwt.2016.10.050

Baskin, S. and Brewer, T. (2010). Cyanide poisoning chapter pharmacology division. Maryland, USA: Army medical research institue of chemical defense, aberdeen proving ground.

Carica, P. (2015). Pengaruh cara pengolahan terhadap sifat fisikokimia pisang tongka langit (Musa troglodytarum). Jurnal Teknologi Pertanian, 4(1), 13-18. https://doi.org/10.30598/ jagritekno.2015.4.1.14 [In Bahasa Indonesia].

Chaturvedi, S., Hemamalini, R. and Khare, S.K. (2012). Effect of processing conditions on saponin content and antioxidant activity of Indian varieties of soybean (Glycine max Linn). Annals of Phytomedicine, 1(1), 62-68.

Clifford, J., Niebaum, K. and Bellows, L. (2015). Dietary Fiber, Food and Nutrition Series Health. Colorado State University, USA: U.S. Department of Agriculture and Colorado counties cooperating.

Damanik, R.N.S., Pratiwi, D.Y.W., Widyastuti, N., Rustanti, N., Anjani, G. and Afifah, D.N. (2018). Nutritional composition changes during tempeh gembus processing. IOP Conference Series: Earth and Environmental Science, 116 012026, 1-10. https://doi.org/10.1088/1755-1315/116/1/012026

Dhinendra, N.P.A., Dewi, E.N. and Romadhon. (2015). Substitusi tepung buah mangrove (Bruguiera gymnorrhiza) terhadap sifat fisika dan kimia naget ikan kurisi (Nemipterus nematophorus). Indonesian Journal of Fisheries Science and Technology, 11(1), 57-61. [In Bahasa Indonesia].

European Food Safety Authority (EFSA). (2012). Scientific opinion on the tolerable upper intake level of calcium. EFSA Journal, 10(7), 2814. https:// doi.org/10.2903/j.efsa.2012.2814

Fajri, R., Basito and Muhammad, D. (2013). Karakteristik fisikokimia dan organoleptik food bars labu uning (Cucurbita maxima) dengan penambahan tepung kedelai dan tepung kacang hijau sebagai alternatif produk pangan darurat. Jurnal Teknologi Hasil Pertanian, 6(2), 103-110. https:// doi.org/10.20961/jthp.v0i0.13524 [In Bahasa Indonesia].

De Garmo, E.P., Sullivan, W.G., Bontadelli, J.A. and Wicks, E.M. (1995). Engineering Economy. New York, USA: Mc Millan Publishing Company.

Ginting, E. and Antarlina, S.S. (2002). Pengaruh varietas dan cara pengolahan terhadap mutu susu kedelai. Penelitian Pertanian Tanaman Pangan, 21(2), 4857. [In Bahasa Indonesia].
Hagerman, A. (2010). Tanin chemistry and biochemistry. USA: Miami University.

Handayani, S. (2018). Identifikasi jenis tanaman mangrove sebagai bahan pangan alternatif. Jurnal Teknologi Pangan, 12(2), 33-46. https:// doi.org/10.33005/jtp.v12i2.1287 [In Bahasa Indonesia].

Hastuti, A. and Afifah, D.N. (2019). Analisis aktivitas antioksidan, analisis kandungan gizi, uji organolepti snack bar sesame seed dan tepung labu kuning sebagai alternatif makanan selingan dengan tinggi antioksidan. Journal of Nutrition College, 8(4), 219230. https://doi.org/10.14710/jnc.v8i4.25835 [In Bahasa Indonesia].

Hawa, A., Satheesh, N. and Kumela, D. (2018). Nutritional and anti-nutritional evaluation of cookies prepared from okara red teff and wheat flours. International Food Research Journal, 25(5), 20422050.

Heldman. (2012). Food Process Engineering Second Edition. Westport, USA: The AVI Company.

Horwitz, W. (ed.) (2005). Official methods of analysis of AOAC International. 18th ed. Virginia USA: AOAC International.

Jacob, J. and Leelavathi, K. (2007). Effect of fat type on cookie dough and cookie quality. Journal of Food Engineering, 79(1), 299-305. https:// doi.org/10.1016/j.jfoodeng.2006.01.058

Jariyah, Enny Karti, B.S., and Pertiwi, Y.A. (2017). Evaluasi sifat fisikokimia food bar dari tepung komposit (pedada, talas, dan kedelai) sebagai alternatif pangan darurat. Jurnal Rekapangan, 11(1), 70-76. [In Bahasa Indonesia].

Ministry of Health of the Republic of Indonesia. (2016). Hasil pemantauan status gizi (PSG) dan penjelasannya. Jakarta, Indonesia: Ministry of Health of the Republic of Indonesia. [In Bahasa Indonesia].

Ministry of Health of the Republic of Indonesia. (2018a). Komposisi Pangan Indonesia 2017. Jakarta, Indonesia: Ministry of Health of the Republic of Indonesia. [In Bahasa Indonesia].

Ministry of Health of the Republic of Indonesia. (2018b). Riset Kesehatan Dasar (Riskedsas). Jakarta, Indonesia: Kementrian Kesehatan. [In Bahasa Indonesia].

Khairy, S., Salem, H. and Samy, M. (2013). Effect of nutritional status on growth pattern of stunted preschool children. Journal of Nutrition, 2(1), 1-9. doi: 10.5829/idosi.ajn.2013.2.1.7466.

Leroy, J., Ruel, M., Habicht, J.P. and Frongillo, E.A. (2014). Linear growth deficit continues to accumulate beyond the first 1000 days in low- and 
middle-income countries. Journal of Nutrition, 144 (9), 1460-1466. https://doi.org/10.3945/ jn.114.191981

Lestaria, T.I., Nurhidajaha and Yusuf, M. (2018). Kadar protein, tekstur dan sifat organoleptik cookies yang disubstitusi tepung ganyong (Cann edulis) dan tepung kacang Kedelai (Glycine max L). Jurnal Pangan Dan Gizi, 8, 53-63. [In Bahasa Indonesia].

Liang, L.Z. and Yi, M.L. (2009). Antioxidant tannins from Syzygium cumini fruit. African Journal of Biotechnology, 8(10), 2301-2309. doi: 10.4314/ ajb.v8i10.60578.

Lönnerdal, B. (2017). Excess iron intake is a factor in the growth, infections, and development of infants and young children. American Journal of Clinical Nutrition, 106(Suppl. 6), 1681-1687. https:// doi.org/10.3945/ajcn.117.156042

Mervina, Clara, M. and Marliyati, S. (2012). Formulasi biskuit dengan substitusi tepung ikan lele dumbo (Clarias gariepinus) dan isolat protein kedelai (Glycine max) sebagai makanan potensial untuk anak balita gizi kurang. Jurnal Teknologi dan Industri Pangan, 23(1), 9-16. [In Bahasa Indonesia].

Mulyatun. (2018). Pemberdayaan masyarakat pesisir berbasis potensi lokal alternatif ketahanan pangan berupa tepung magrove. Dimas Jurnal Pemikiran Agama untuk Pemberdayaan, 18(2), 211-238. https://doi.org/10.21580/dms.2018.182.3260 [In Bahasa Indonesia].

Negara, J.K., Sio, A.K., Rifkhan, Arifin, M., Oktaviana, A.Y., Wihansah, R.R.S. and Yusuf, M. (2016). Aspek mikrobiologi serta Sensori (rasa, warna, tekstur, aroma) pada dua bentuk penyajian keju yang berbeda. Jurnal Ilmu Produksi dan Teknologi Hasil Peternakan, 4(2), 286-290. https://doi.org/10.29244/ jipthp.4.2.286-290 [In Bahasa Indonesia].

Nilasari, O.W., Susanto, W.H. and Maligan, J.M. (2017). Pengaruh suhu dan lama pemasakan terhadap karakteristik lempok labu kuning (waluh). Jurnal Pangan dan Agroindustri, 5(3), 15-26. [In Bahasa Indonesia].

Okoye, J. and Nkwocha, A. (2008). Production, proximate composition and consumer acceptability of biscuits from wheat/soybean flour blends. Journal Food Science and Technology, 28(2), 6-13.

Pangastuti, H., Affandi, D. and Ishartanti (2013). Karakteristik sifat fisik dan kimia tepung kacang merah (Phaseolus vulgaris L) dengan beberapa perlakuan pendahuluan. Jurnal Teknosains Pangan, 2(1), 20-29. [In Bahasa Indonesia].

Peraturan Menteri Kesehatan Republik Indonesia. (2016). Standar makanan tambahan untuk anak balita. In Standar produk suplementasi gizi, p. 8-12. Indonesia: Menteri Kesehatan Republik Indonesia [In Bahasa Indonesia].

Perdana, Y.S., Nirwani and Supriyantini, E. (2012). Pengaruh kadar abu gosok selama perebusan dan lama perendaman air terhadap kadar tanin buah dan tepung mangrove (Avicennia marina). Journal of Marine Research, 1(2), 226-234.

Purwanto, P. and Hersoelistyorini, W. (2011). Studi pembuatan makanan pendamping asi (Mp-Asi) menggunakan campuran tepung kecambah kacang kedelai, kacang hijau dan beras. Jurnal Pangan dan Gizi, 2(3), 43-54. doi: 10.26714/jpg.2.1.2011. [In Bahasa Indonesia].

Rahmaningsih, A., Surti, T. and Anggo, A. (2016). Pengaruh penambahan tepung buah lindur (Bruguiera gymnorrhiza) terhadap kualitas biskuit ikan lele (Clarias batrachus). Jurnal Pengetahuan and Biotek, 5(3), 52-59. https://doi.org/10.1007/ s11187-017-9901-7 [In Bahasa Indonesia].

Rajapakse, N. (2015). Development of a method to remove beany flavor. Food Science and Technology, 2(1), 21-25.

Ramadhan, R., Nuryanto and Wijayanti, H. (2019). Kandungan gizi dan daya terima cookies berbasis tepung ikan teri (Stolephorus $s p$ ) sebagai PMT-P untuk balita gizi kurang. Journal of Nutrition College, 8(4), 264-273. https://doi.org/10.14710/ jnc.v8i4.25840 [In Bahasa Indonesia].

Rosyadi, E., Widjanarko, S.B. and Ningtyas, D.W. (2014). Pembuatan lempeng buah lindur (Bruguiera gymnorrhiza) dengan penambahan tepung ubi kayu (Manihot esculenta crantz). Jurnal Pangan dan Agroindustri, 2(4), 10-17.

Sandjaja. (2009). Kamus gizi pelengkap kesehatan keluarga. Jakarta: PT. Kompas Medida Nusantara. [In Bahasa Indonesia].

Sari, F.D.N. and Astili, R. (2018). Kandungan asam sianida dendeng dari limbah kulit singkong. Jurnal Dunia Gizi, 1(1), 20-29. https://doi.org/10.33085/ jdg.vli1.2899

Sarofa, U. and Yulistiani, R. (2013). Pemanfaatan tepung buah lindur (Bruguiera gymnirrhiza) dalam pembuatan crackers dengan penambahan gluten. Jurnal Teknologi Pangan, 13(2), 13-18. [In Bahasa Indonesia].

SCF (Scientific Committee on Food). (2003). Opinion on the tolerable upper intake level of calcium. SCF/CS/ NUT/UPPLEV/64 Final. Italy: European Food Safety Authority.

Semba, R.D., Shardell, M., Ashour, F.A.S., Moaddel, R., Trehan, I., Maleta, K.M., Ordiz, M.I., Kraemer, K., 
Khadeer, M.A., Ferucci, L. and Manary, M.J. (2016). Child Stunting is associated with low circulating essential amino acids. Ebiomedicine Journal, 6, 246252. https://doi.org/10.1016/j.ebiom.2016.02.030

Setianingsih, N.I. (2016). Extraction process for reducing tannin of mangrove fruit as a raw material for food flour. Journal Aquatic Procedia, 7(2), 231-235. https://doi.org/10.1016/j.aqpro.2016.07.032

Stuijvenberg, M.E.V., Nel, J., Schoeman, S.E., Lombard, C.J., Plesis, L.M.D. and Dansay, M.A. (2015). Low intake calcium and vitamin $\mathrm{D}$, but not zinc, iron or vitamin $\mathrm{A}$, is associated with stunting in 2- to 5- year -old children. Nutrition, 31(6), 841-846. https:// doi.org/10.1016/j.nut.2014.12.011

Sudirman, S., Nurjanah and Jacoeb, A.M. (2014). Proximate compositions, bioactive compounds and antioxidant activity from large-leafed mangrove (Bruguiera gymnorrhiza) fruit. International Food Research Journal, 21(6), 2387-2391.

Sulistyawati, Wignyanto and Kumalaningsih, S. (2012). Produksi tepung buah lindur (Bruguiera gymnorrhiza) rendah tanin dan HCN sebagai bahan pangan alternatif. Jurnal Teknologi Pertanian, 13 (13), 187-198. [In Bahasa Indonesia].

Sundari, D., Almasyhuri, A. and Lamid, A. (2015). Pengaruh proses pemasakan terhadap komposisi zat gizi bahan pangan sumber protein. Media Penelitian dan Pengembangan Kesehatan, 25(4), 235-242. https://doi.org/10.22435/mpk.v25i4.4590.235-242 [In Bahasa Indonesia].

Sundari, E. and Nuryanto (2016). Hubungan asupan protein, seng, zat besi, dan riwayat penyakit infeksi dengan z-score tb/u pada balita. Journal of Nutrition College, 5(4), 520-529. [In Bahasa Indonesia].

Tien, R. and Fitriyono, A. (2010). Teknologi proses pengolahan pangan. Bandung, Indonesia: Alfabeta. [In Bahasa Indonesia].

Tim Nasional Percepatan Penanggulangan Kemiskinan. (2017). 100 kabupaten/ kota prioritas untuk intervensi anak kerdil (stunting). Jakarta, Indones: Tim Nasional Percepatan Penanggulangan Kemiskinan. [In Bahasa Indonesia].

Yang, A., Smyth, H. and Chaliha. (2016). Sensory quality of soymilk and tofu from soybeans lacking lipoxygenases. Food Science and Nutrition, 4(2), 207-215. https://doi.org/10.1002/fsn3.274 